\title{
TINGKAT PENGETAHUAN AKUNTAN MUDA DALAM MENJAGA EKSISTENSI AKUNTANSI SYARIAH GUNA MENYONGSONG INDONESIA EMAS 2045
}

\author{
Gusti B'tari Artichah', Gracia Angelina Nawang Wulan² \\ Universitas Negeri Malang1,2,Jl. Semarang No. 5 Malang, 65145, Indonesia \\ e-mail: gusti.btari.1804226@students.um.ac.id1
}

\begin{abstract}
Accounting has undergone many developments in line with efforts to adapt to the needs of stakeholders. This development can be seen from the introduction of sharia-based accounting principles with the emergence of many sharia transactions offered by sharia entities. This is the background for the birth of SAK Syariah which was ratified in 2007. With the development of studies on Islamic accounting in Indonesia, accountants are required to equip themselves with good knowledge of Islamic accounting. Therefore, this study aims to determine the Islamic accounting knowledge of young accountants in order to welcome Indonesia Golden era 2045 in terms of their knowledge of Islamic accounting. This research is a descriptive study using a quantitative approach with a survey method. The results found that the knowledge of sharia accounting possessed by young accountants was still considered less ready to contribute to realizing Indonesia Golden era 2045. It was also found that the factors that led to the lack of knowledge of sharia accounting experienced by young accountants namely: lack of literature, lack of practice-based learning, lack of educators who are experts in their fields, religious stereotypes, assumptions are the same as conventional accounting. Furthermore, this study suggests optimizing young accountants' understanding of Islamic accounting in addition to conventional accounting. This is beneficial for efforts to develop Islamic accounting in Indonesia and for Islamic institutions to be able to present financial reports correctly and adequately.
\end{abstract}

Keywords: knowledge; sharia accounting; young accountants

\begin{abstract}
Abstrak
Bidang akuntansi telah banyak mengalami perkembangan seiring dengan upaya untuk menyesuaikan kebutuhan stakeholders. Perkembangan tersebut dapat dilihat dari dikenalnya prinsip akuntansi berbasis syariah dengan muncul banyaknya transaksi syariah yang ditawarkan oleh entitas syariah. Hal tersebut yang melatarbelakangi lahirnya SAK Syariah yang disahkan pada tahun 2007. Dengan berkembangnya kajian mengenai akuntansi syariah di Indonesia, para akuntan dituntut untuk membekali diri dengan pengetahuan yang baik mengenai akuntansi syariah. Oleh karena itu, penelitian ini bertujuan untuk mengetahui pengetahuan akuntansi syariah akuntan muda guna menyongsong Indonesia Emas 2045 ditinjau dari pengetahuan mereka mengenai akuntansi syariah. Penelitian ini merupakan penelitian deskriptif menggunakan pendekatan kuantitatif dengan metode survei. Hasil penelitian menunjukkan bahwa pengetahuan akuntansi syariah yang dimiliki oleh akuntan muda masih dinilai kurang siap untuk turut berkontribusi dalam mewujudkan Indonesia Emas 2045. Ditemukan pula faktor yang menyebabkan kurangnya pengetahuan akuntansi syariah yang dialami oleh akuntan muda, yaitu: kurangnya literatur, kurangnya pembelajaran berbasis praktik, kurangnya tenaga pendidik yang ahli dibidangnya, stereotip agama, anggapan sama dengan akuntansi konvensional. Selanjutnya penelitian ini menyarankan untuk melakukan optimalisasi pemahaman akuntan muda terhadap akuntansi syariah disamping akuntansi konvensional. Hal tersebut tidak hanya bermanfaat bagi upaya pengembangan akuntansi syariah di Indonesia namun bermanfaat pula bagi lembaga syariah agar dapat menyajikan laporan keuangan secara baik dan benar.
\end{abstract}

Kata kunci: pengetahuan; akuntansi syariah; akuntan muda 
Gusti B'tari Artichah ${ }^{1}$ dan Gracia Angelina Nawang Wulan ${ }^{2}$ : Tingkat Pengetahuan Akuntan Muda Dalam Menjaga Eksistensi Akuntansi Syariah Guna Menyongsong Indonesia Emas 2045

\section{PENDAHULUAN}

Indonesia Emas 2045 telah menjadi cita-cita bangsa Indonesia dalam upaya pengembangan dari segala bidang. Menurut Manullang (2013), untuk membangun kehidupan berbangsa yang lebih baik maka diperlukan Sumber Daya Manusia (SDM) yang berdaya saing. Oleh karena itu, Indonesia harus melakukan investasi secara besar-besaran dalam bidang pengembangan SDM (Dongoran, 2014). Selain upaya pengembangan SDM, cita-cita lain yang tercantum dalam Indonesia Emas 2045 adalah pengembangan ekonomi yang berkelanjutan. Terdapat hubungan yang berkesinambungan di mana dalam pengembangan ekonomi dapat dilakukan melalui peningkatan kualitas SDM khsususnya pada profesi akuntan yang dituntut untuk mengoptimalkan kontribusinya dalam mewujudkan Indonesia Emas 2045.

Akuntansi telah mengalami banyak perkembangan salah satunya adalah prinsip akuntansi berbasis syariah yang melahirkan Standar Akuntansi Keuangan Syariah (SAK Syariah) pada tahun 2007. Perkembangan ini merupakan upaya dalam memenuhi kebutuhan stakeholders terkait dengan munculnya transaksi syariah. Di sektor keuangan, terdapat 436 institusi keuangan syariah di Indonesia pada tahun 2018 (Otoritas Jasa Keuangan, 2018). Sedangkan di sektor halal bisnis, pengeluaran Indonesia mencapai US\$218,8Bn di tahun 2017 (Indonesia Halal Lifestyle Center, 2019). Selain itu, menurut Hariyanto (2017), yang menyatakan bahwa pemerintah Indonesia telah membuat terobosan baru dalam mencari sumber pembiayaan khusus infrastruktur dengan menerbitkan Sukuk Negara atau obligasi syariah yang berbasis Project Based Sukuk (PBS). Kemudian pemerintah telah menetapkan Undang-Undang Nomor 19 Tahun 2008 tentang Surat Berharga Syariah Negara (SBSN) yang menjadi payung hukum bagi kelancaran aktivitas investasi syariah yang nantinya akan berguna bagi pembiayaan pembangunan infrasturuktur di Indonesia (Helmi, 2015). Hariyanto (2017) juga menyatakan bahwa nantinya akan terjadi peningkatan pembangunan infrastruktur di Indonesia seperti pembangunan waduk untuk PLTA dan pertanian, pembangunan jalan tol, pelabuhan pelayaran, dan lain-lain. Oleh karena itu, seiring dengan kebijakan pemerintah dalam upaya peningkatan pembangunan infrastruktur, maka peran SBSN PBS di masa depan akan terus meningkat karena kemampuannya yang dinilai baik dalam pembiayaan proyek berskala besar. Berdasarkan uraian di atas, dapat disimpulkan bahwa kebutuhan terhadap akuntansi syariah akan meningkat seiring dengan peningkatan transaksi atau praktik syariah di Indonesia. Dari hal tersebut, dapat dikatakan pula bahwa praktik syariah sebenarnya telah berkembang dengan baik di Indonesia, namun dari sisi pelaporan keuangan dalam bentuk syariah yang dinilai masih perlu dikaji dalam proses perkembangannya.

Penelitian yang dilakukan oleh Rahmanti (2012) menemukan tiga faktor yang menyebabkan akuntansi syariah sulit berkembang di Indonesia, yaitu pertama, penilaian praktik perbankan syariah di Indonesia dikatakan masih jauh dari syariat Islam. Kedua, stereotip masyarakat yang menganggap bahwa akuntansi syariah tidak berbeda secara substansial dari akuntansi konvensional. Dan ketiga, faktor SDM yang 
Gusti B'tari Artichah ${ }^{1}$ dan Gracia Angelina Nawang Wulan ${ }^{2}$ : Tingkat Pengetahuan Akuntan Muda Dalam Menjaga Eksistensi Akuntansi Syariah Guna Menyongsong Indonesia Emas 2045

berupa kekurangpahaman dan keengganan mereka untuk memahami akuntansi syariah yang menyebabkan praktik akuntansi syariah kurang diimplementasikan. Ketiga hal tersebut apabila diacuhkan dan tidak segera dibenahi, maka akuntansi syariah sulit mencapai perkembangan sehingga membahayakan eksistensinya. Senada, Himawati \& Subono (2009) yang menyarankan agar praktisi dan akademisi untuk terus mengembangkan praktik syariah terutama pada bidang manufaktur atau produksi barang di Indonesia. Untuk itu, akuntan muda memegang peranan penting untuk meningkatkan kondisi tersebut dan melakukan perkembangan terhadap akuntansi syariah agar dapat memperbaiki perekonomian Indonesia dalam menyambut Indonesia Emas 2045. Berdasarkan penelitian sebelumnya oleh Arwani (2016) menyatakan bahwa kesiapan para akuntan syariah Indonesia dalam memasuki MEA 2016 wajib menyiapkan beberapa hal, antara lain: standar akuntansi syariah, memahami risiko syariah, memenuhi instrumen pada pasar keuangan syariah yang kurang, upaya untuk meningkatkan akuntan syariah, akuntan syariah memiliki pemahaman dan kemampuan mengenai IPTEK. Oleh karena itu, fokus penelitian ini adalah untuk melihat sejauh mana pengetahuan akuntansi syariah akuntan muda untuk berperan dan berkontribusi dalam menyambut Indonesia Emas 2045. Akuntan muda dikatakan pihak yang dapat berperan aktif dalam memenuhi permintaan dan tuntutan instansi untuk melaporkan keuangan secara efektif dan efisien sesuai dengan kaidah Islam. Selain itu, penelitian ini untuk mengetahui faktor apa saja yang mempengaruhi tingkat pengetahuan akuntan muda.

\section{METODE}

Jenis penelitian ini merupakan penelitian deskriptif. Tujuan dari jenis penelitian deskriptif adalah untuk membuat deskripsi secara sistematis, faktual dan akurat mengenai berbagai fakta dan sifat dari populasi atau suatu objek tertentu yang diteliti (Kriyantono dalam Ardian, 2008:68). Tipe penelitian jenis deskriptif umumnya berkaitan dengan opini dari individu, kelompok maupun organisasional (Indriantoro \& Supomo, 2018: 26). Penelitian ini nantinya akan menyusun deskripsi secara akurat dan sistematis terhadap objek yang diteliti yaitu kesiapan akuntan muda yang ditinjau dari pengetahuan mengenai akuntansi syariah.

Target responden yang dituju dalam penelitian ini adalah akuntan muda atau akuntan muda yang tergabung menjadi anggota dari Ikatan Akuntan Indonesia Muda (IAI Muda). Berdasarkan situs web iaiglobal.or.id, terdapat tiga keanggotaan dalam IAI, salah satunya adalah Anggota Muda yang mempunyai ketentuan, yaitu: "Mahasiswa DIII/DIV/S1 Akuntansi program studi akuntansi atau pendidikan akuntansi". Oleh karena itu, populasi dari penelitian ini adalah seluruh akuntan muda yang menjadi anggota dari IAI Muda di Indonesia. Sedangkan sampel dalam penelitian adalah akuntan muda yang tergabung dalam IAI Muda wilayah Jawa Timur. Hal tersebut merujuk pada situs web iaijawatimur.or.id menuliskan bahwa IAI Jawa Timur merupakan pelopor berdirinya IAI Muda di Indonesia dan dibuktikan dengan terus meningkatnya anggota IAI wilayah Jawa Timur dari tahun 
Gusti B'tari Artichah ${ }^{1}$ dan Gracia Angelina Nawang Wulan ${ }^{2}$ : Tingkat Pengetahuan Akuntan Muda Dalam Menjaga Eksistensi Akuntansi Syariah Guna Menyongsong Indonesia Emas 2045

ke tahun terutama pada jumlah anggota IAI Mudanya. Atau dapat dikatakan bahwa jumlah akuntan muda terbanyak berada di wilayah Jawa Timur.

Kuesioner disusun melalui Google Form dan disebarkan melalui sosial media. Responden dapat berasal dari seluruh perguruan tinggi di Jawa Timur yang merupakan anggota IAI Muda dan bersedia mengisi kuesioner. Hasil dari kuesioner yang terisi oleh responden akan dianalisis untuk menemukan jawaban dari rumusan masalah yang telah disusun. Teknik pengumpulan data dilakukan melalui 2 cara, yaitu

\section{1) Teknik Survei}

Peneliti mengumpulkan data dari responden dengan menggunakan kuesioner. Pertanyaan yang diajukan dalam kuesioner merupakan bentuk pertanyaan tertutup sehingga responden dapat langsung memilih jawaban yang telah disediakan. Kuesioner terdiri dari sepuluh pertanyaan terkait materi akuntansi syariah dasar yang disusun berdasarkan Rencana Perkuliahan Semester (RPS) mata kuliah akuntansi syariah. Kuesioner disusun menggunakan Google Form dan disebar berdasarkan target responden yang telah ditentukan.

Dikarenakan peneliti mengumpulkan data menggunakan kuesioner, maka perlu dilakukan uji validitas untuk menilai tingkat akurasi pertanyaan yang telah disusun. Menurut Indriantoro \& Supomo (2018), suatu instrumen pengukur dinyatakan valid jika instrumen tersebut mengukur apa yang seharusnya diukur. Jika penelitian ini mengukur tingkat pengetahuan mengenai akuntansi syariah maka indikator yang digunakan dalam mengukur pengetahuan tersebut adalah pemahaman, pengertian, dan perbedaan.

Uji validitas yang digunakan dalam penelitian ini adalah uji ahli materi yang berupa tanggapan atau penilaian dari ahli materi, kemudian dari hasil tersebut akan dianalisis dan dilakukan revisi agar sesuai dengan saran yang diberikan (Ernawati \& Sukardiyono, 2017). Uji ahli materi dilakukan oleh salah satu dosen jurusan akuntansi yang mengampu mata kuliah akuntansi syariah. Ahli materi nantinya akan memberikan skor dengan rentang satu hingga lima terhadap empat pertanyaan yang diajukan peneliti mengenai apakah telah sesuai antara kuesioner yang disusun dengan tujuan yang ingin dicapai dalam penelitian. Hasil dari pemberian skor oleh uji materi nantinya akan dianalisis untuk menentukan valid tidaknya kuesioner penelitian. Uji ahli materi ditunjukkan dalam Tabel 1.

Berdasarkan perhitungan Tabel 2, rata-rata skor yang telah diberikan oleh ahli materi menunjukkan angka 4 yang berarti bahwa kuesioner dinilai telah sesuai dengan tujuan penelitian. Dengan hasil uji ahli materi tersebut, maka kuesioner telah dinyatakan valid untuk diajukan kepada responden. Peneliti telah melakukan survei dengan menyebar kuesioner melalui Google Form kepada responden yakni, para akuntan muda atau dalam penelitian ini adalah anggota dari IAI Muda Jawa Timur dan didapatkan hasil sebanyak 34 responden dari 44 formulir kuesoner yang telah didistribusikan. Seluruh responden menyatakan bahwa mereka merupakan anggota dari IAI Muda Jawa Timur. Hal tersebut sesuai 
Gusti B'tari Artichah ${ }^{1}$ dan Gracia Angelina Nawang Wulan ${ }^{2}$ : Tingkat Pengetahuan Akuntan Muda Dalam Menjaga Eksistensi Akuntansi Syariah Guna Menyongsong Indonesia Emas 2045

dengan target yang ditentukan yaitu responden yang menjadi anggota IAI Muda atau dapat dikatakan sebagai akuntan muda.

Tabel 1. Hasil Uji Ahli Materi

\begin{tabular}{|l|l|c|c|c|c|c|}
\hline No & \multicolumn{1}{|c|}{ Pertanyaan } & $\begin{array}{c}\text { Skor } \\
\mathbf{1}\end{array}$ & $\begin{array}{c}\text { Skor } \\
\mathbf{2}\end{array}$ & $\begin{array}{c}\text { Skor } \\
\mathbf{3}\end{array}$ & $\begin{array}{c}\text { Skor } \\
\mathbf{4}\end{array}$ & $\begin{array}{c}\text { Skor } \\
\mathbf{5}\end{array}$ \\
\hline 1. & $\begin{array}{l}\text { Apakah kuesioner telah mengukur } \\
\text { pengetahuan dalam membedakan } \\
\text { akuntansi syariah dan akuntansi } \\
\text { konvensional? }\end{array}$ & $\begin{array}{l}\text { Xn } \\
\text { pengetahuan dalam memahami } \\
\text { prinsip, konsep dan mekanisme } \\
\text { akuntansi syariah? }\end{array}$ & $\mathbf{X}$ & & & $\mathbf{X}$ \\
\hline 3. & $\begin{array}{l}\text { Apakah kuesioner telah mengukur } \\
\text { pengetahuan dalam memahami } \\
\text { contoh kasus dari akuntansi syariah? }\end{array}$ & & & & $\mathbf{X}$ \\
\hline 4. & $\begin{array}{l}\text { Apakah materi dalam kuesioner } \\
\text { merupakan materi dasar yang harus } \\
\text { dimiliki oleh akuntan muda? }\end{array}$ & & & & \\
\hline
\end{tabular}

Tabel 2. Kriteria Kesesuaian Soal Menggunakan Skala Likert

\begin{tabular}{|c|c|}
\hline Skor & Kategori Kelayakan \\
\hline 1 & Sangat Tidak Sesuai \\
\hline 2 & Tidak Sesuai \\
\hline 3 & Cukup \\
\hline 4 & Sesuai \\
\hline 5 & Sangat Sesuai \\
\hline
\end{tabular}

Perhitungan Rata-Rata Nilai dari Uji

Materi:

$$
\begin{aligned}
\text { Rata-rata } & =\frac{5+2+4+5}{4} \\
& =\frac{16}{4} \\
& =4
\end{aligned}
$$

Berikut isi dari kuesioner yang telah ditentukan:

\section{1) Angkatan}

Identitas berupa angkatan untuk memastikan bahwa responden terdiri dari beberapa angkatan. Hal tersebut bermanfaat untuk mencegah kecenderungan mahasiswa angkatan tertentu mengenai tanggapannya terhadap kuesioner penelitian.

2) Jurusan

Identitas berupa jurusan untuk memastikan bahwa responden telah memenuhi syarat untuk menjadi sampel penelitian yaitu anggota IAI Muda yang menempuh jurusan akuntansi atau pendidikan akuntansi. 
Gusti B'tari Artichah ${ }^{1}$ dan Gracia Angelina Nawang Wulan ${ }^{2}$ : Tingkat Pengetahuan Akuntan Muda Dalam Menjaga Eksistensi Akuntansi Syariah Guna Menyongsong Indonesia Emas 2045

\section{3) Keanggotaan dari IAI Muda}

Identitas berupa pernyataan keanggotaan IAI Muda berguna untuk mengetahui dan memastikan bahwa responden telah memenuhi syarat untuk dijadikan sampel penelitian yaitu menjadi anggota IAI Muda.

\section{4) Asal Perguruan Tinggi}

Perguruan tinggi yang diisi oleh responden guna untuk mengonfirmasi apakah responden memenuhi kriteria penelitian yaitu anggota IAI Muda wilayah Jawa Timur. Hasil kuesioner menunjukkan bahwa 34 responden tersebar dari 27 perguruan tinggi di Jawa Timur.

\section{5) Sepuluh butir pertanyaan terkait akuntansi syariah}

Pertanyaan disusun berdasarkan pedoman RPS mata kuliah akuntansi syariah yang sebelumnya telah dilakukan uji ahli materi dan dinyatakan valid. 10 pertanyaan merupakan materi akuntansi syariah dasar yang ditempuh mahasiswa dalam mata kuliah akuntansi syariah.

Selanjutnya akan dilakukan penyebaran kuesioner, responden dari penelitian ini berjumlah 34 yang merupakan mahasiswa/mahasiswi anggota IAI Muda Jawa Timur. Jumlah tersebut telah lebih besar dari 30 responden dan lebih kecil dari 500, sehingga cocok dipakai untuk kebanyakan penelitian (Alwi, 2015). Minimal populasi untuk penelitian deskriptif adalah $10 \%$ populasi dan $20 \%$ untuk populasi yang relatif kecil, sehingga sampel yang diperlukan adalah 15-30 responden (Gay, Mills, dan Airasian, 2009:133). Tingkat akurasi data didukung oleh jumlah sampel 30 responden.

\section{2) Teknik Wawancara}

Selain kuesioner, penelitian ini juga menggunakan teknik wawancara sebagai alat pengumpul data. Teknik wawancara merupakan teknik di mana peneliti menggali informasi berupa fakta dan data secara akurat kepada narasumber (Rosaliza, 2015). Dikarenakan kondisi saat penelitian yang kurang mendukung, wawancara tidak dilakukan secara tatap muka namun melalui media komunikasi daring yaitu aplikasi WhatsApp. Meskipun begitu, wawancara tetap dilakukan secara mendalam untuk memperoleh informasi dan tanggapan narasumber terkait dengan penelitian.

Wawancara bertujuan untuk mencari tahu apa faktor yang menyebabkan tingkat pengetahuan akuntansi syariah responden. Sehingga wawancara ini bersifat menguatkan dan menjelaskan mengenai data yang diperoleh saat pengajuan kuesioner. Jawaban dari responden saat wawancara nantinya akan dianalisis untuk mengetahui faktor yang menyebabkan tinggi atau rendahnya pengetahuan akuntan muda.

Hasil dari kuesioner yang telah terkumpul dianalisis berdasarkan tingkat pengetahuan responden mengenai materi akuntansi syariah. Semakin tinggi skor yang dihasilkan oleh responden dalam mengisi kuesioner akan dinyatakan semakin memiliki pengetahuan atau pemahaman mengenai akuntansi syariah. Tingkat 
Gusti B'tari Artichah ${ }^{1}$ dan Gracia Angelina Nawang Wulan ${ }^{2}$ : Tingkat Pengetahuan Akuntan Muda Dalam Menjaga Eksistensi Akuntansi Syariah Guna Menyongsong Indonesia Emas 2045

pengetahuan atau pemahaman responden sebagai akutan muda mengenai akuntansi syariah akan berbanding lurus dan selaras dengan tingkat kesiapan mereka dalam menyongsong Indonesia Emas 2045. Hasil analisis dari kuesioner yang diajukan peneliti kemudian akan disimpulkan untuk dapat menjadi usulan bagi pihak yang berkepentingan dalam upaya pembuatan kebijakan. Sedangkan teknik pengumpulan data melalui wawancara dianalisis untuk memperoleh faktor yang menyebabkan tinggi atau rendahnya pengetahuan responden mengenai akuntansi syariah. Peneliti akan menyusun narasi secara terperinci berdasarkan jawaban dari responden.

\section{HASIL DAN PEMBAHASAN}

Dapat disimpulkan bahwa responden yang diperoleh pada penelitian ini telah cukup memadai dalam pengambilan data. Berikut hasil penelitian berupa diagram berdasarkan data yang diperoleh dari responden:

1. Responden berdasarkan angkatan; jurusan; anggota IAI muda; asal perguruan tinggi, yakni:

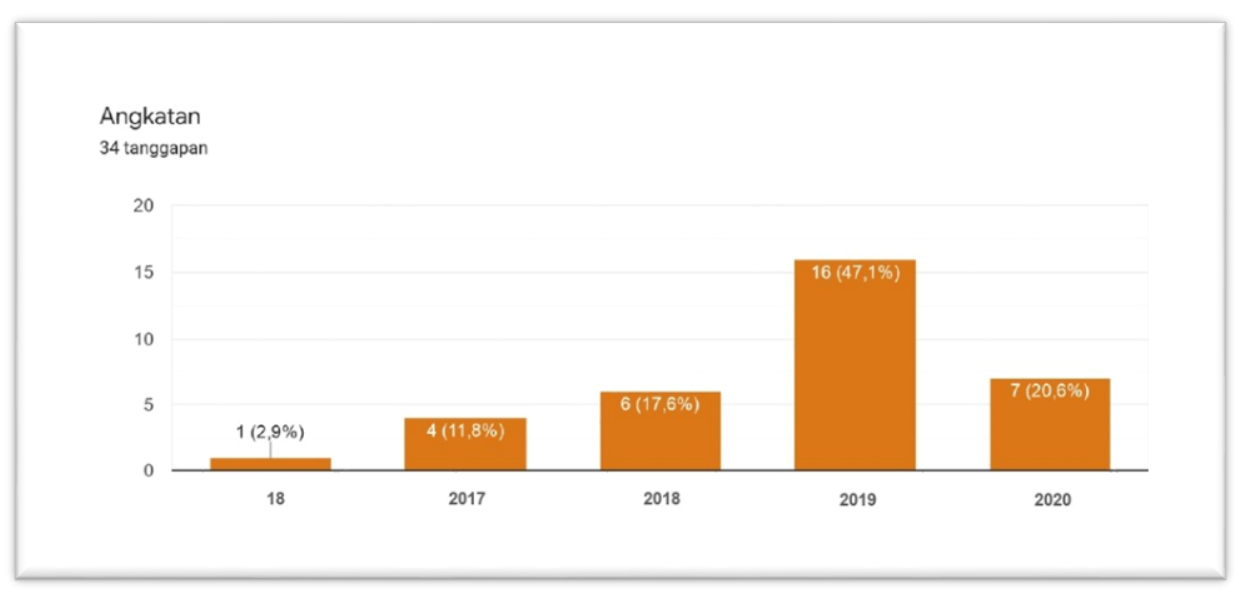

\section{Gambar 1. Diagram persentase responden berdasarkan angkatan}

Pertama berdasarkan pada gambar 1, dapat diketahui bahwa responden tersebar mulai dari angkatan 2017 hingga 2020. Sebanyak 7 (20,6\%) responden merupakan angkatan 2020, angkatan 2019 sebanyak 16 (47,1\%) responden, angkatan 2018 sebanyak 7 (20,5\%) responden, dan angkatan 2017 sebanyak 4 $(11,8 \%)$ responden. Tingkat responden yang tertinggi adalah pada tahun 2019 dengan $47,1 \%$ atau sebanyak 16 responden.

Dari survei tersebut menunjukkan bahwa kuesioner yang diisi oleh responden telah tersebar dari angkatan 2017 hingga 2020. Sehingga penelitian ini menjadi lebih representatif karena tidak hanya melihat dari sisi angkatan tertentu atau mahasiswa baru maupun mahasiswa lama namun melihat dari sisi mahasiswa secara kolektif.

Kedua hasil presentase responden sebanyak 20,6\% atau 7 responden berasal dari jurusan pendidikan akuntansi sedangkan sisanya sebanyak 79,4\% atau 27 responden berasal dari jurusan pendidikan akuntansi. Keseluruhan 
Gusti B'tari Artichah ${ }^{1}$ dan Gracia Angelina Nawang Wulan ${ }^{2}$ : Tingkat Pengetahuan Akuntan Muda Dalam Menjaga Eksistensi Akuntansi Syariah Guna Menyongsong Indonesia Emas 2045

responden yang menempuh jurusan akuntansi maupun pendidikan akuntansi menunjukkan bahwa responden telah memenuhi syarat menjadi anggota IAI Muda dan sesuai dengan kriteria untuk dijadikan sampel penelitian. Di sisi lain, tingginya persentase responden yang berasal dari jurusan akuntansi dapat menjadikan penelitian ini lebih efektif karena jurusan akuntansi dikenal menghasilkan calon akuntan profesional lebih tinggi dibanding jurusan pendidikan akuntansi yang berpotensi menjadi akuntan pendidik.

Ketiga berdasarkan kuesioner yang telah diisi oleh 34 responden IAI Muda Jawa Timur, dari 27 asal perguruan tinggi seluruh responden berada di wilayah Jawa Timur. Hal tersebut dikatakan sesuai dengan kriteria yang ditetapkan oleh peneliti yaitu anggota IAI Muda yang berada di wilayah Jawa Timur.

2. Hasil Jawaban Responden dari Sepuluh Butir Soal Akuntansi Syariah, yakni:

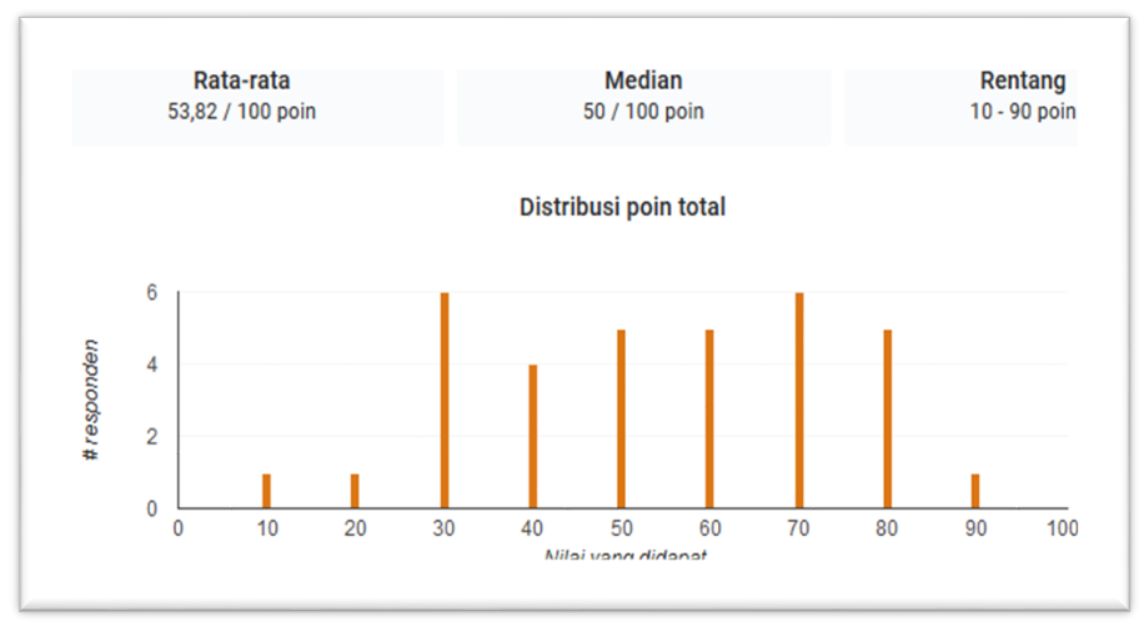

\section{Gambar 3. Diagram Hasil Jawaban Responden dari 10 Butir Soal Akuntansi Syariah}

Berdasarkan gambar 4, hasil penelitian mengindikasikan bahwa rentan nilai yang diperoleh berkisar antara 10 sampai dengan 90 poin dengan rata-rata 53,82 dari skala 100. Tidak ada nilai sempurna atau semua jawaban benar yang diperoleh responden karena tidak ada yang memperoleh nilai 100. Melainkan hanya satu responden dengan nilai tertinggi yaitu sebesar 90. Nilai terendah diperoleh satu responden dengan nilai 10, yang artinya hanya satu jawaban yang benar. Sedangkan modus atau nilai yang sering muncul adalah nilai 30 dan 70 karena masing-masing diperoleh enam responden.

Berdasarkan survei yang telah dilakukan dengan para responden, dapat disimpulkan bahwa pemahaman akuntan muda terhadap dasar-dasar akuntansi syariah yang menjadi indikator pemahaman responden masih rendah dan belum cukup baik untuk siap menyongsong Indonesia Emas 2045. Hal tersebut dapat menjadi dasar sebuah studi pendahuluan untuk mengevaluasi kelayakan dan rancangan dari suatu penelitian, sehingga dapat 
dilaksanakan proyek penelitian skala penuh. Di mana rata-rata pemahaman para responden terkait dengan akuntansi syariah masih jauh dari standar yang menjadi pedoman dasar dalam menentukan pencapaian hasil belajar, untuk itu perlu dioptimalkan salah satunya melalui perguruan tinggi.

Dengan rendahnya pengetahuan akuntan muda terhadap dasar-dasar akuntansi syariah, maka akuntan muda belum dikatakan siap dalam menjaga eksistensi akuntansi syariah guna menyongsong Indonesia Emas 2045. Di sisi lain, eksistensi akuntansi syariah harus tetap terjaga karena akuntansi syariah telah dinilai baik semenjak adanya transaksi atau praktik syariah yang dijadikan alternatif bagi pemerintah untuk mencari sumber pembiayaan infrastruktur negara. Tidak hanya itu, praktik syariah juga mengalami peningkatan secara pesat dengan bertambah majunya lembaga keuangan syariah, halal bisnis, investasi syariah, dan lain-lain. Seiring dengan meningkatnya praktik syariah sekaligus menjadi tanda perkembangan akuntansi syariah di Indonesia, maka akuntan muda diharapkan dapat memiliki kompetensi di bidang akuntansi syariah. Selain itu, akuntan muda dituntut untuk berperan aktif dan berkontribusi secara maksimal dalam upaya pengembangan serta mempertahankan eksistensi akuntansi syariah agar siap untuk menyongsong Indonesia Emas 2045.

Hasil wawancara dilakukan terhadap dua perwakilan responden, yaitu satu responden dengan nilai di atas rata-rata $(53,82)$ dan satu responden dengan nilai di bawah rata-rata. Dikarenakan hasil survei penelitian yang menyatakan tingkat pengetahuan akuntansi syariah para responden masih dikatakan kurang, maka peneliti melakukan wawancara untuk mencari informasi mengenai faktor apa saja yang menyebabkan kurangnya pengetahuan akuntan muda mengenai dasardasar akuntansi syariah. Faktor-faktor yang ditemui selama proses wawancara antara lain adalah:

1. Kurangnya literatur dan bahan referensi yang disediakan oleh perguruan tinggi. Responden menyatakan bahwa tingkat pengetahuan disebabkan oleh faktor kurangnya respon dari pihak perguruan tinggi yang tidak memberikan cukup fasilitas literatur yang dapat diakses dengan mudah oleh responden. Responden juga menyarankan bahwa sebaiknya mahasiswa memiliki inisiatif untuk mencari dan membekali ilmu akuntansi syariah di media lain seiring dengan kurangnya fasilitas yang disediakan oleh perguruan tinggi.

2. Kurangnya pembelajaran berbasis praktik dalam mata kuliah akuntansi Syariah. Responden menyatakan bahwa model pembelajaran juga sangat mempengaruhi terserapnya pengetahuan yang diberikan oleh dosen. Pemberian ilmu berupa teori dinilai kurang mudah diterima tanpa adanya contoh nyata, penyelesaian kasus, dan ilmu praktik yang diberikan selama proses perkuliahan.

3. Kurangnya tenaga pendidik yang secara khusus memiliki ahli di bidang akuntansi Syariah. Responden menyatakan bahwa tenaga pendidik perlu 
memiliki spesifikasi dan keahlian khusus dibidang yang terkait, baik ekonomi syariah, keuangan syariah, atau akuntansi syariah. Hal tersebut dapat meningkatkan kualitas ilmu yang akan disampaikan kepada mahasiswa saat perkuliahan berlangsung.

4. Anggapan bahwa akuntansi syariah hanya untuk dipelajari oleh akuntan muslim. Akuntan muda merasa kurang tertarik dengan mata kuliah akuntansi syariah dikarenakan faktor agama dan budaya. Salah satu responden mengatakan bahwa Indonesia merupakan negara multireligi, maka dengan adanya akuntansi syariah akan muncul anggapan bahwa akuntansi syariah hanya dikhususkan untuk segmen tertentu yaitu segmen akuntan muslim. Hal tersebut yang menyebabkan beberapa akuntan muda kurang tertarik dan merasa enggan untuk mempelajari akuntansi syariah.

5. Anggapan bahwa akuntansi syariah tidak jauh berbeda dengan akuntansi konvensional. Anggapan itulah yang menyebabkan mahasiswa kurang atau tidak mempelajari akuntansi syariah. Karena menurut mereka mempelajari akuntansi konvensional sama saja mempelajari akuntansi syariah. Salah satu responden mengatakan bahwa pernah menemui lembaga syariah yang belum menerapkan sistem akuntansi syariah melainkan menggunakan sistem akuntansi konvensional. Hal tersebut yang mengakibatkan munculnya anggapan bahwa akuntansi syariah dan akuntansi konvensional tidak jauh berbeda.

\section{KESIMPULAN}

Hasil survei menunjukkan nilai rata-rata yang diperoleh responden sebesar 53,82 dari skala 100. Hal tersebut dapat menjadi dasar studi pendahuluan yang mengindikasikan bahwa pengetahuan akuntan muda terhadap dasar-dasar akuntansi syariah dinilai kurang dan belum cukup baik untuk siap dalam menyongsong Indonesia Emas 2045. Sehingga dapat dievaluasi kelayakan dan rancangan dari penelitian ini untuk dilaksanakan penelitian skala penuh. Dimana dengan rendahnya pengetahuan akuntan muda, maka dapat membahayakan eksistensi akuntansi syariah di Indonesia. Di sisi lain, eksistensi akuntansi syariah harus tetap terjaga karena akuntansi syariah telah dinilai baik semenjak adanya transaksi atau praktik syariah yang dijadikan alternatif bagi pemerintah untuk mencari sumber pembiayaan infrastruktur negara. Oleh karena itu, seiring dengan meningkatnya praktik syariah yang sekaligus menjadi tanda perkembangan akuntansi syariah di Indonesia, maka akuntan muda diharapkan dapat memiliki kompetensi dibidang akuntansi syariah. Selain itu, akuntan muda dituntut untuk berperan aktif dan berkontribusi secara maksimal dalam upaya pengembangan serta mempertahankan eksistensi akuntansi syariah agar siap untuk menyongsong Indonesia Emas 2045.

Terdapat faktor-faktor yang mempengaruhi rendahnya pengetahuan akuntan muda terhadap akuntansi syariah, diantaranya adalah: Kurangnya literatur dan 
Gusti B'tari Artichah ${ }^{1}$ dan Gracia Angelina Nawang Wulan ${ }^{2}$ : Tingkat Pengetahuan Akuntan Muda Dalam Menjaga Eksistensi Akuntansi Syariah Guna Menyongsong Indonesia Emas 2045

bahan referensi yang disediakan oleh perguruan tinggi, Kurangnya pembelajaran berbasis praktik dalam mata kuliah akuntansi syariah, Kurangnya tenaga pendidik yang secara khusus memiliki ahli di bidang akuntansi syariah, Anggapan bahwa akuntansi syariah hanya untuk dipelajari oleh akuntan muslim, Anggapan bahwa akuntansi syariah tidak jauh berbeda dengan akuntansi konvensional.

Penelitian ini memiliki keterbatasan, yaitu: dikarenakan penyebaran kuesioner melalui internet, maka peneliti tidak dapat melakukan pengawasan secara langsung terhadap proses pengisian kuesioner yang dilakukan oleh responden. Hal tersebut memungkinkan memberi peluang bagi responden untuk bertindak curang. Selain itu, dikarenakan situasi pandemi COVID-19 yang menyebabkan proses wawancara tidak dilakukan secara tatap muka yang memungkinan kurangnya penyampaian informasi secara mendalam oleh responden. Jumalah responden yang sedikit, maka peneliti perlu memperluas populasi dan sampel penelitian agar hasilnya lebih representatif. Hal tersebut dapat berdampak pada hasil penelitian yang belum mencukupi untuk generalisasi.

\section{DAFTAR PUSTAKA}

Ardian, M. (2013). Sikap Masyarakat Surabaya Terhadap Program Acara "Pesbukers" di ANTV. Jurnal E-Komunikasi, $1(1), \quad 1{ }^{-} 11$. http://publication.petra.ac.id/index.php/ilmukomunikasi/article/view/113.

Alwi, I. (2015). Kriteria Empirik dalam Menentukan Ukuran Sampel Pada Pengujian Hipotesis Statistika dan Analisis Butir. FORMATIF: Jurnal Ilmiah Pendidikan MIPA, 2(2), 140 148. http:/ / dx.doi.org/10.30998/formatif.v2i2.95.

Arwani, A. (2016). Profesi Akuntan Syariah Indonesia Memasuki Masyarakat Ekonomi Asean (MEA). Muqtasid: Jurnal Ekonomi Dan Perbankan Syariah, 7(1), 163. https://doi.org/10.18326/muqtasid.v7i1.163-184

Dongoran, F. R. (2014). Paradigma Membangun Generasi Emas 2045 dalam Perspektif Filsafat Pendidikan. Jurnal Tabularasa PPS UNIMED, 11(1), 61-76. http://jurnal.unimed.ac.id/2012/index.php/tabularasa/article/view/3336

Ernawati, I., \& Sukardiyono, T. (2017). UJI KELAYAKAN MEDIA PEMBELAJARAN INTERAKTIF PADA MATA PELAJARAN ADMINISTRASI SERVER. Elinvo (Electronics, Informatics, and Vocational Education), 2(2), 204-210. https://doi.org/https://doi.org/10.21831/elinvo.v2i2.17315

Hariyanto, E. (2017). Memahami Project Based Sukuk ( PBS ). 5. http:// www.djppr.kemenkeu.go.id/uploads/files/Kajian_Artikel_DJPPR/Me mahami PBS.pdf

Helmi, A. (2015). Komparasi Pembiayan Pembangunan Infrastruktur Pemerintah Dengan Dana Obligasi Konvensional Dan Obligasi Syariah / Sukuk (Studi Kasus Pembangunan Jalan Tol Trans Sumatera). Yogyakarta: UIN Sunan Kalijaga. TESIS, h. 1-85.

Himawati, S., \& Subono, A. (2009). PRAKTIK AKUNTANSI DAN PERKEMBANGAN AKUNTANSI SYARIAH DI INDONESIA. Sosial Budaya, 2(2), ISSN 1979-6889. http://jurnal.umk.ac.id/?page_id=443

Ikatan Akuntan Indonesia. (2020). Membership - IAI Global. In Ikatan Akuntan Indonesia. http://iaiglobal.or.id/v03/keanggotaan/ca_aktif/home 
Gusti B'tari Artichah ${ }^{1}$ dan Gracia Angelina Nawang Wulan ${ }^{2}$ : Tingkat Pengetahuan Akuntan Muda Dalam Menjaga Eksistensi Akuntansi Syariah Guna Menyongsong Indonesia Emas 2045

Indriantoro, N. \& Supomo, B. (2018). Metodologi Penelitian Bisnis Untuk Akuntansi dan Manajemen. Edisi 1. Cetakan ke-1. Yogyakarta: ANDI Publisher.

Manullang, B. (2013). Grand Desain Pendidikan Karakter Generasi Emas 2045. Jurnal Pendidikan Karakter, 3(1), 1 14. https://doi.org/10.21831/jpk.v0i1.1283.

Nieuwsbericht. (2019). Indonesia Halal Economy and Strategy Roadmap 2018/2019 Launched. Indonesia Halal Lifestyle Center (Online), (https://agroberichtenbuitenland.nl/landeninformatie/indonesie/nieuws/ 2019/04/02/indonesia-halal-economy-and-strategy-roadmap-2018-2019launched), diakses 22 Agustus 2021.

Laporan Pengembangan Keuangan Syariah Indonesia (LPKSI) .(2018). Otoritas Jasa Keuangan (Online), (https://ojk.go.id/id/kanal/syariah/data-danstatistik/laporan-perkembangan-keuangan-syariahindonesia/Pages/2018.aspx), diakses 22 Agustus 2021.

Rahmanti, V. N. (2012). Sebuah Kajian Mengapa Akuntansi Syariah Masih Sulit Tumbuh Subur di Indonesia. Journal of Accounting and Investment, 13(2), 161-179. https://journal.umy.ac.id/index.php/ai/article/view/486/622

Rosaliza, M. (2015). Wawancara, Sebuah Interaksi Komunikasi dalam Penelitian $\begin{array}{lllll}\text { Kualitatif. Jurnal Ilmu Budaya, } & \text { 11(2), }\end{array}$ https://doi.org/https://doi.org/10.31849/jib.v11i2.1099 